\title{
Isoprene in poplar emissions: effects on new particle formation and OH concentrations
}

\author{
A. Kiendler-Scharr ${ }^{1}$, S. Andres ${ }^{1}$, M. Bachner ${ }^{1}$, K. Behnke ${ }^{2, *}$, S. Broch ${ }^{1}$, A. Hofzumahaus ${ }^{1}$, F. Holland ${ }^{1}$, E. Kleist ${ }^{3}$, \\ T. F. Mentel ${ }^{1}$, F. Rubach ${ }^{1}$, M. Springer ${ }^{1}$, B. Steitz ${ }^{1}$, R. Tillmann ${ }^{1}$, A. Wahner ${ }^{1}$, J.-P. Schnitzler ${ }^{2, *}$, and J. Wildt ${ }^{3}$ \\ ${ }^{1}$ Institute of Energy and Climate Research, Troposphere (IEK-8), Forschungszentrum Jülich GmbH, Jülich, Germany \\ ${ }^{2}$ Institute of Meteorology and Climate Research, Karlsruhe Institute of Technology, Garmisch-Partenkirchen, Germany \\ ${ }^{3}$ Institute of Bio- and Geosciences, Plant Sciences (IBG-2), Forschungszentrum Jülich GmbH, Jülich, Germany \\ * present address: Research Unit Environmental Simulation, Institute of Biochemical Plant Pathology, Helmholtz Zentrum \\ München, Neuherberg, Germany
}

Correspondence to: A. Kiendler-Scharr (a.kiendler-scharr@fz-juelich.de)

Received: 15 June 2011 - Published in Atmos. Chem. Phys. Discuss.: 8 August 2011

Revised: 21 December 2011 - Accepted: 13 January 2012 - Published: 20 January 2012

\begin{abstract}
Stress-induced volatile organic compound (VOC) emissions from transgenic Grey poplar modified in isoprene emission potential were used for the investigation of photochemical secondary organic aerosol (SOA) formation. In poplar, acute ozone stress induces the emission of a wide array of VOCs dominated by sesquiterpenes and aromatic VOCs. Constitutive light-dependent emission of isoprene ranged between $66 \mathrm{nmol} \mathrm{m}^{-2} \mathrm{~s}^{-1}$ in non-transgenic controls (wild type WT) and nearly zero $\left(<0.5 \mathrm{nmol} \mathrm{m}^{-2} \mathrm{~s}^{-1}\right)$ in isoprene emission-repressed plants (line RA22), respectively. Nucleation rates of up to $3600 \mathrm{~cm}^{-3} \mathrm{~s}^{-1}$ were observed in our experiments. In the presence of isoprene new particle formation was suppressed compared to non-isoprene containing VOC mixtures. Compared to isoprene/monoterpene systems emitted from other plants the suppression of nucleation by isoprene was less effective for the VOC mixture emitted from stressed poplar. This is explained by the observed high efficiency of new particle formation for emissions from stressed poplar. Direct measurements of $\mathrm{OH}$ in the reaction chamber revealed that the steady state concentration of $\mathrm{OH}$ is lower in the presence of isoprene than in the absence of isoprene, supporting the hypothesis that isoprenes' suppressing effect on nucleation is related to radical chemistry. In order to test whether isoprene contributes to SOA mass formation, fully deuterated isoprene $\left(\mathrm{C}_{5} \mathrm{D}_{8}\right)$ was added to the stress-induced emission profile of an isoprene free poplar mutant. Mass spectral analysis showed that, despite the isoprene-induced suppression of particle formation, fractions of deuterated isoprene were incorporated into the
\end{abstract}

SOA. A fractional mass yield of $2.3 \%$ of isoprene was observed. Future emission changes due to land use and climate change may therefore affect both gas phase oxidation capacity and new particle number formation.

\section{Introduction}

Land vegetation is the major source of volatile organic compounds (VOC) in the troposphere (Guenther et al., 1995). Biogenic VOC impact atmospheric oxidation capacity (e.g. Fuentes et al., 2000) and serve as precursors for secondary organic aerosols (SOA) (Hallquist et al., 2009). In regions with low pre-existing particulate matter, VOC oxidation can produce low volatile products which are involved in new particle formation (Tunved et al., 2006). Emissions of isoprene and monoterpenes (MT) from vegetation are well known and their dependence on parameters such as light intensity and temperature can be described semi-empirically (Guenther, 2007).

Recent literature points out that isoprene - the most important single VOC emitted from land vegetation - is poorly understood both in terms of gas phase oxidation mechanism (Lelieveld et al., 2008; Hofzumahaus et al., 2009; Paulot et al., 2009; Peeters and Müller, 2010) and its impact on new particle formation (Kiendler-Scharr et al., 2009b). Observations of atmospheric $\mathrm{OH}$ concentrations indicate that under low $\mathrm{NO}_{\mathrm{x}}$ conditions isoprene may be involved in a so far unidentified recycling mechanism that converts $\mathrm{HO}_{2}$ into $\mathrm{OH}$ 
without involving ozone formation (Tan et al., 2001; Thornton et al., 2002; Ren et al., 2008; Lelieveld et al., 2008; Hofzumahaus et al., 2009; Whalley et al., 2011; Lu et al., 2011). Contrary, suppression of new particle formation by isoprene was ascribed to its suppression of $\mathrm{OH}$ concentrations (Kiendler-Scharr et al., 2009b). Recent field observations also indicate a suppression of particle formation by isoprene (Kanawade et al., 2011).

Many VOCs, including isoprene, are emitted constitutively and the emissions can be observed throughout the life cycle of the plant or, more often, at specific developmental stages. The emission is biosynthetically controlled by abiotic factors such as light and/or temperature, atmospheric $\mathrm{CO}_{2}$ concentration, or nutrition (Loreto and Schnitzler, 2010). Other VOCs are induced after wounding and herbivore feeding (Holopainen and Gershenzon, 2010) or after environmental stresses such as ozone exposure (Heiden et al., 2003). The biosynthesis of most VOCs can be assigned to the following three major pathways: terpenoid synthesis (=isoprenoids), octadecanoid pathway (= green leaf volatiles), and shikimate pathway (= aromatic VOCs, Dudareva et al., 2004). Low molecular weight, $\mathrm{C}_{1}$ and $\mathrm{C}_{2}$ - compounds, such as methanol, ethanol, formaldehyde, and acetaldehyde can be synthesized via other biosynthetic routes (Kreuzwieser et al., 1999). Current estimates assume that between $2-5 \%$ of the photosynthetically assimilated carbon are released in the form of VOCs (Kesselmeier et al., 2002; Ghirardo et al., 2011) and in general stress increases VOC emissions. Despite all information on VOCs biosynthesis and biological and ecological functions (for reviews see Holopainen and Gershenzon, 2010; Loreto and Schnitzler, 2010) there is limited information about the role of these VOCs in secondary organic aerosol formation. It can be assumed that some of them are important for SOA formation but currently not considered in models. Atmospheric oxidation of stress-induced biogenic compounds possibly also contributes to aerosol secondary growth, i.e., condensation of organic components onto preexisting aerosols.

Changing VOC emission patterns in response to climate change may add an additional dimension to an expected feedback mechanism between climate-biosphere and atmosphere. It was proposed previously that an increase in biogenic VOC emissions in response to increasing temperatures will increase atmospheric SOA formation, which in turn can lead to an increased negative forcing induced by atmospheric aerosol particles (Kulmala et al., 2004). As was shown by Kiendler-Scharr et al. (2009b) changes in emission patterns can drastically change the new particle formation potential of VOC mixtures. Future SOA formation from biogenic VOCs will therefore not only depend on the total amount of VOCs emitted from an ecosystem but also on the relative abundance of certain VOC or VOC-classes in the emission mixtures.

The high multitude of biogenic VOCs does not allow for the investigation of their individual impact on aerosol formation. Nevertheless, to better understand and quantify possible feedback effects between climate, air chemistry, and the biosphere, the knowledge of impacts from all compounds is imperative. To obtain more realistic emission scenarios in laboratory environments it is of eminent importance to use plants as a direct source for aerosol precursors. Such experiments realistically integrate the diverse aspects of the large diversity of compounds in the atmosphere as compared to experiments with individual compounds (McFiggans et al., 2004; Joutsensaari et al., 2005; VanReken et al., 2006; KiendlerScharr et al., 2009a, b; Mentel et al., 2009; Hao et al., 2009, 2011; Lang-Yona et al., 2010).

We investigated the new particle formation and secondary organic aerosol mass formed from poplar emissions. Poplars are not only among the strongest emitters of isoprene (Kesselmeier and Staudt, 1999) but as a fast growing pioneer tree, also these plants receive enormous attention due to increasing demand of renewable bioenergy (Schnitzler et al., 2010). World-wide poplar plantations represent 5.3 million ha with an increasingly positive trend in many countries (International Poplar Commission, Synthesis of Country Progress Reports 2008). Wiedinmyer et al. (2006) developed expected land use changes in model-based estimates of future changes in global isoprene emissions. Their simulations revealed that the conversion of natural vegetation to plantations (poplar and others, e.g. oil palm and eucalypts) could substantially increase global isoprene flux up to $37 \%$ compared with the current situation. Moreover, the potential of genetic manipulation offers the opportunity to analyze poplar mutants with different VOC emission pattern. Here, we used wild type poplars (WT) naturally emitting high rates of isoprene and transgenic lines in which isoprene emission is repressed by RNA interference (for detail see Behnke et al., 2007) to analyse differences in new particle formation potential of different natural biogenic VOC mixtures. Exposing single trees to high ozone concentrations as a proxy for pathogen-induced stress reactions (Sandermann et al., 1998) changed the emission pattern and strength significantly (Behnke et al., 2009) thus assessing a wide range of VOC compositions and their contribution to new particle formation in the absence and presence of isoprene. Using such typical stress-induced VOC emissions from Grey poplar plants for photochemical SOA formation we found very high nucleation rates of up to $3600 \mathrm{~cm}^{-3} \mathrm{~s}^{-1}$ in nonisoprene emitting mutants. We furthermore measured a suppression of nucleation by isoprene, either by external isoprene added to the reaction mixture or in the natural isoprene emitter type. In order to test whether isoprene despite of suppressing new particle number formation takes part in SOA mass formation, an experiment was performed in which fully deuterated isoprene $\left(\mathrm{C}_{5} \mathrm{D}_{8}\right)$ was added to the emissions of the non-isoprene emitting poplar mutant. Mass spectral analysis showed that fractions of isoprene were incorporated in the SOA formed from the other BVOC. Suppression of nucleation by isoprene was similar to that described for isoprene/MT systems (Kiendler-Scharr et al., 2009b). However, 
compared to isoprene/MT systems the suppression of nucleation by isoprene was less effective for the VOC mixture emitted from stressed poplar.

\section{Experimental}

\subsection{Set-up}

Experiments were performed in the Jülich plant atmosphere chamber (JPAC). The set-up and its use in simulating SOA formation from whole plant emissions is described in detail by Mentel et al. (2009). A short summary is given here.

The set-up consisted of two glass chambers each of them in a temperature-controlled walk in climate chamber. A chamber with a volume of $164 \mathrm{~L}$ served as plant chamber; the other one (volume 1450 L) was used as reaction chamber. Both chambers were operated as continuous stirred reactors with residence times of $8 \mathrm{~min}$ and $60 \mathrm{~min}$, respectively. Purified outside air was flushed through the plant chamber where it took up plant emitted VOCs. A fraction of the air leaving the plant chamber was fed into the reaction chamber.

In order to study the impact of VOC on particle formation the emissions of the plants were varied at otherwise unchanged conditions in the reaction chamber. Thus for reproducible conditions the relative humidity and $\mathrm{O}_{3}$ concentration in the reaction chamber were kept constant. As described in Mentel et al. (2009) SOA formation in the reaction chamber was induced by $\mathrm{OH}$ initiated oxidation. $\mathrm{OH}$ was formed from ozone photolysis by a UV lamp (Philips TUV, $\lambda_{\max }=254 \mathrm{~nm}$ ) installed in the reaction chamber. For the experiments described here the temperature and $\mathrm{RH}$ in the reaction chamber were kept at $17{ }^{\circ} \mathrm{C}$ and $63 \%$, respectively. $\mathrm{O}_{3}$ concentrations were around $90 \mathrm{ppb}$ when the UV light was off and dropped to around $40 \mathrm{ppb}$ when the UV light was on. Hence $\mathrm{O}_{3}$ concentrations were comparable to atmospheric concentrations. Note that the $\mathrm{OH}$ concentration ranged from $5 \times 10^{6}$ to $7.6 \times 10^{7} \mathrm{~cm}^{-3}$ which is roughly one magnitude larger than typically observed in the atmosphere. Also VOC concentrations ranged from $5 \mathrm{ppbC}$ for non-isoprene emitting mutants under low stress conditions to $450 \mathrm{ppbC}$ for stressed plants. While this is quite high compared to atmospheric observations in the remote atmosphere, the VOC concentrations used here are low compared to most other laboratory studies.

\subsection{Materials and methods}

Experiments were conducted with five- to six-month-old plants of wild type Grey poplars (Populus $x$ canescens (Aiton) Sm.) and a well characterized transgenic line (RA22) in which gene expression of isoprene synthase (PcISPS) was knocked down by RNAi silencing (35S::PcISPS-RNAi, for further information on this line see Behnke et al., 2007). The plants were grown in the greenhouse in $2.2 \mathrm{~L}$ pots with soil substrate (25\% (v/v) Fruhsdorfer Einheitserde (Bayerische Gärtnereigenossenschaft, München, Germany), $25 \%$ (v/v) silica sand (particle size 1-3 mm), 50\% (v/v) perlite (Agriperl Dämmstoff GmbH, Dortmund, Germany)), and 10 g fertilizer (Triabon (Compo, Münster, Germany): Osmocote (Scotts International B.V., Heerlen, The Netherlands), 1:1 (v/v) per L of soil) moistened with tap water.

The experiments were conducted using individual plants in the plant chamber (10 experiments with 3 isoprene emitting individuals and 15 experiments with 6 non-isoprene emitting individuals). Temperature $\left(28^{\circ} \mathrm{C}\right)$ and light intensity (permanent illumination, PPFD $=800 \mu \mathrm{mol} \mathrm{m}^{-2} \mathrm{~s}^{-1}$ ) were held constant. After introducing a plant, each of them (WT and RA22) was exposed to an acute ozone pulse of $750 \mathrm{ppb}$ ozone for $120 \mathrm{~min}$ with ozone stress-induced emissions appearing few hours after exposure (see also Behnke et al., 2009).

Particle formation was studied once per day and in some cases the plants were held for up to 5 days under permanent illumination. Thus, an impact of the permanent light as an additional stress factor with impact on the emissions cannot be excluded. However, the emissions of the poplar trees in these experiments can be classified as stress-induced.

In one experiment fully deuterated isoprene $\left(\mathrm{C}_{5} \mathrm{D}_{8}\right.$, Polymer Source Inc., Canada) was added to the emissions of a non-isoprene emitting poplar mutant. Thereby the fraction of isoprene that contributed to SOA mass formation could be determined (see below).

\subsection{Instrumentation}

Ozone (Thermo Environment Model 49), NOx (ECO Physics CLD 770 AL ppt+PLC 760), RH (Vaisala, HMP 235), $\mathrm{H}_{2} \mathrm{O}$ (dew point mirror Walz MTS-MK1), and temperatures (thermo sensors, Newport Omega), were monitored using standard instrumentation.

VOC concentrations were measured using gas chromatograph coupled to mass spectrometer (GC-MS) systems (Agilent GC 7890A with MSD 5975 C) and a PTR-MS (High sensitivity proton transfer reaction mass spectrometer, Ionicon Analytik). Both systems were calibrated using diffusion sources as described in Heiden et al. (2003). The GC-MS systems were used to measure concentrations of VOCs at the exit of the plant chamber allowing speciation of the emitted compounds, determining emission rates and enabling quantification of the amount of VOC entering the reaction chamber. The PTR-MS was switched every 30 minutes between outlet of the plant chamber and outlet of the reaction chamber to allow measuring concentration differences of classes of VOC. In case of isoprene or methyl salicylate concentration differences of individual VOCs were measured with a high temporal resolution (3 $\mathrm{min}$ ).

During experiments without addition of deuterated isoprene, isoprene concentrations were determined at $m / z=67$ with the GC-MS and at $m / z=69$ with the PTR-MS. Deuterated isoprene was measured at $m / z=74$ with the GC-MS 
system and at $m / z=77$ with the PTR-MS. Interferences by oxidation products limited the PTR-MS measurements of deuterated isoprene concentrations to the outlet of the plant chamber. For determining the concentrations of deuterated isoprene we assumed that the ionisation efficiencies for deuterated isoprene was the same as that for isoprene with natural isotope abundance.

$\mathrm{OH}$ concentrations were measured by laser-induced fluorescence (LIF). For this purpose, a new instrument was deployed that had been developed for airborne application as a follow-up version of the instrument outlined by Holland et al. (2003). Here, the instrument was attached to the reaction chamber. Air was continuously sampled from the chamber by gas expansion through a $0.6 \mathrm{~mm}$ nozzle into a low pressure $(6 \mathrm{hPa})$ detection cell, in which $\mathrm{OH}$ was detected by pulsed laser-excited fluorescence at $308 \mathrm{~nm}$. Unlike in previous instrument configurations (Holland et al., 2003; Lu et al., 2011), a long inlet tube (anodized aluminium) with a length of $22 \mathrm{~cm}$ and an internal diameter of $3.9 \mathrm{~cm}$ connected the nozzle to the fluorescence cell. This allowed in-situ measurement of $\mathrm{OH}$ in the reaction chamber at a distance of about $20 \mathrm{~cm}$ from the chamber bottom and the sidewall surfaces. Since the inlet tube slows down the gas flow through the detection cell, the pulse repetition frequency of the laser was reduced to $3 \mathrm{kHz}$ in order to avoid build-up of artificial $\mathrm{OH}$ by laser photolysis of ozone inside the instrument. A residual interference signal corresponding to an $\mathrm{OH}$ concentration of about $1 \times 10^{6} \mathrm{~cm}^{-3}$ was present during the chamber experiments and was subtracted from the $\mathrm{OH}$ measurements. For calibration, the $\mathrm{OH}$ detection device was completely removed from the chamber and exposed to a calibration source that produces $\mathrm{OH}$ by photolysis of water vapour at $185 \mathrm{~nm}$ (Holland et al., 2003). The detection limit of the LIF instrument was $5 \times 10^{5} \mathrm{~cm}^{-3}(\mathrm{SNR}=2)$ at a time resolution of $3.5 \mathrm{~min}$.

Physical characterisation of the aerosol was achieved with a Condensation Particle Counter (CPC, TSI3022) and SMPS (TSI3071+TSI3025A) measuring the aerosol number concentration and size distribution respectively. From these data together with BVOC consumption, number efficiencies and incremental mass yields were calculated as described in detail in Mentel et al. (2009).

Aerosol composition was measured using a highresolution time of flight aerosol mass spectrometer (HR-ToFAMS). The HR-ToF-AMS (hereafter referred to as AMS) is described in detail elsewhere (Canagaratna et al., 2007). Briefly the AMS allows the mass spectrometric online investigation of aerosol particle composition after substantial reduction of the gas phase. The AMS was calibrated for ionization efficiency with $\mathrm{NH}_{4} \mathrm{NO}_{3}$ aerosol and particle size calibrated using polystyrol latex (PSL, Duke Scientific Corporation, Palo Alto CA) standards of 8 different sizes between $81 \mathrm{~nm}$ and $596 \mathrm{~nm}$. The data analysis strategy applied in interpreting the aerosol mass spectrometric features of SOA formed from plant emitted VOCs was similar to that previously described (Kiendler-Scharr et al., 2009a). Only a brief summary of the high resolution related aspects of data analysis is given here. The residuum mass spectrum from gas phase interferences was obtained during periods with no SOA in the reaction chamber. The information from these background measurements was implemented in the so called - fragmentation wave used to account for the airbeam signal in the AMS (Allan et al., 2004). High resolution data was obtained in $\mathrm{V}$ - and $\mathrm{W}$-mode of the mass spectrometer (see Canagaratna et al., 2007).

In order to quantify the fraction of SOA formed from $\mathrm{C}_{5} \mathrm{D}_{8}$ during the experiment with addition of fully deuterated isoprene, the ion peaks containing $\mathrm{C}, \mathrm{D}$, and $\mathrm{O}$ were assigned to deuterated particulate mass $\left(\mathrm{PM}_{\mathrm{D}}\right)$. The following ions could be identified and measured in the experiment: $\mathrm{C}_{2} \mathrm{D}_{3}^{+}$, $\mathrm{C}_{3} \mathrm{D}_{5}^{+}, \mathrm{C}_{2} \mathrm{D}_{3} \mathrm{O}^{+}, \mathrm{C}_{3} \mathrm{D}_{6}^{+}, \mathrm{C}_{2} \mathrm{D}_{4} \mathrm{O}^{+}, \mathrm{C}_{4} \mathrm{D}_{6}^{+}, \mathrm{C}_{4} \mathrm{D}_{7}^{+}, \mathrm{C}_{3} \mathrm{D}_{5} \mathrm{O}^{+}$, $\mathrm{C}_{5} \mathrm{D}_{7}^{+}$, and $\mathrm{C}_{4} \mathrm{D}_{6} \mathrm{O}^{+}$. The sum of signals from these ions was defined as deuterated particulate mass $\left(\mathrm{PM}_{D}\right)$ with mass concentration derived assuming the same relative ionization efficiency (i.e. 1.4) and collection efficiency (i.e. 1, see also Kiendler-Scharr et al., 2009a) as for other organics formed in the experiment.

\section{Results and discussion}

Without stress application the emission of WT poplar was dominated by isoprene. Emissions of other compounds were low. For poplar suppressed in isoprene emissions all emissions were low. Some hours after stressing the plants with ozone they emitted aromatic VOCs originating from the shikimate pathway and terpenoids such as mono-, sesqui-, and homoterpenes (e.g. Behnke et al., 2009). All these emissions increased steadily up to saturation. The amount of carbon released as stress-induced VOCs reached values well above $10 \%$ of $\mathrm{C}$ taken up by net $\mathrm{CO}_{2}$ assimilation. The wild type plants emitted isoprene emissions in addition. Under these conditions the emission pattern was dominated by methyl salicylate and $\alpha$-farnesene. Over the entire period of experiments the constitutive emission of isoprene either stayed relatively constant or decreased slightly after stress application in both type of mutants.

Figure 1 shows the temporal evolution of emission rates of isoprene (red triangles), sum of all monoterpenes (MT, green triangles), sum of sesquiterpenes (SQT, green circles), and sum of aromatic compounds (brown circles) at the example of an isoprene-emitting poplar. Emission rates were determined from the measured VOC concentrations at the plant chamber outlet using the one-sided leaf area as reference for the biomass as described in e.g. Heiden et al. (2003). As depicted in Fig. 1 isoprene emissions were quite constant whereas other VOC emissions increased over time, causing systematic changes of the emission pattern with decreasing contribution of isoprene to the total VOC emissions. 


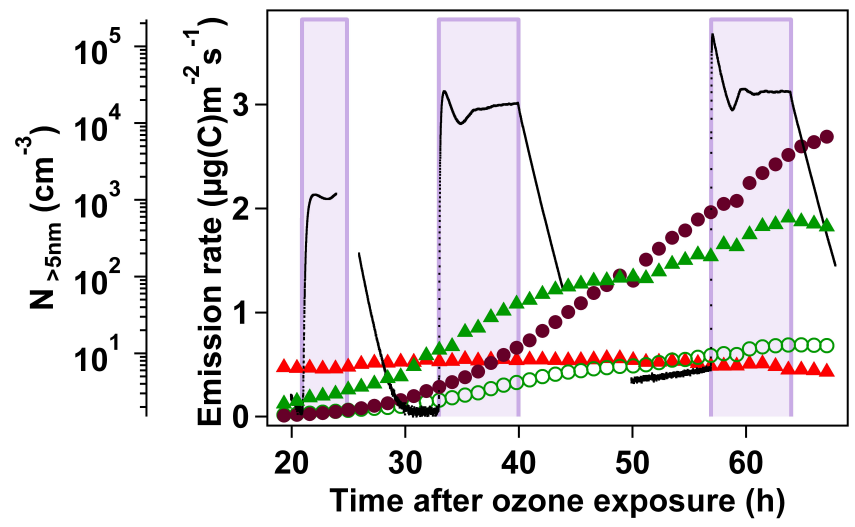

Fig. 1. Temporal evolution of VOC emissions from a wild type Grey poplar plant after chronic ozone exposure. While isoprene (red triangles) is unaffected, the sum of all monoterpenes (MT, green triangles, for clearer visualization MTx100 is displayed), sum of sesquiterpenes (SQT, green circles), and sum of aromatic compounds (brown circles) increase after ozone exposure. During episodes of photochemical simulation in the reaction chamber (purple shaded areas) new particle formation is observed with the number concentration (black dotted line) increasing with increasing VOC concentration.

Overall, the total amount of emitted $\mathrm{C}$ increased with time. In the example of Fig. 1, the total amount of $\mathrm{C}$ in the VOCs emission accounted for $\sim 3 \%$ of the photosynthetically assimilated carbon initially and increased after chronic ozone exposure to $>10 \%$.

The emission pattern of the non-isoprene emitting poplar mutant (Ra22-line) was composed of sesquiterpenes (30$40 \%)$, aromatic VOCs (32-64\%) and to a lower extent monoterpenes $(0.2-2 \%)$. Main difference between the emission pattern of WT and R-line poplars was the contribution of isoprene. For WT poplar the contribution of isoprene ranged from nearly $100 \%$ (unstressed) to $<20 \%$ (stressed) (Fig. 1). In non-isoprene emitting poplar the isoprene contribution to the overall value ranged from $50 \%$ to $<1 \%$ (not shown). Emission rates of SQT and aromatic VOCs were similar in WT and mutant types.

Conducting particle formation experiments at different times in these changing emissions allowed studying the influence of isoprene on new particle formation in a natural mixture of VOCs for wild type poplars. Rising VOC emissions (Fig. 1) led to increasing particle number concentrations (black dots) during the particle formation events (indicated by purple shaded areas in Fig. 1). Particle formation events in emissions from the non-isoprene emitting transgenic line served as reference experiments, determining the efficiency of particle number and mass formation in sesquiterpene and aromatic VOC dominated emission mixtures. Since we observed similar composition of VOC emission with respect to mono- and sesquiterpenes, as well as aromatic VOCs, we as- cribe the lower nucleation rates observed for isoprene emitting WT poplar to the abundance of isoprene.

Overall we found that the sesquiterpene and aromatic VOC dominated emissions of Grey poplar showed a slightly larger efficiency for new particle formation than was found for mainly monoterpene emitting tree species. The number efficiency found here was $6.4( \pm 1.2) \mathrm{s}^{-1} \mathrm{~cm}^{-3} \mathrm{ppb} \mathrm{C}^{-1}$ compared to a maximum of $6.1( \pm 0.4) \mathrm{s}^{-1} \mathrm{~cm}^{-3} \mathrm{ppb} \mathrm{C}^{-1}$ observed for birch trees and $4.7( \pm 0.4) \mathrm{s}^{-1} \mathrm{~cm}^{-3} \mathrm{ppb} \mathrm{C}^{-1}$ for pines (Mentel et al., 2009), respectively. Note that if not stated otherwise standard deviations are reported. Similarly the volume efficiency for Grey poplar emissions was found to be $66.7( \pm 19.7) \times 10^{6} \mathrm{~nm}^{3} \mathrm{~cm}^{-3} \mathrm{ppb} \mathrm{C}^{-1}$, well above observations made by Mentel et al. (2009) for birch $\left(47( \pm 5) \times 10^{6} \mathrm{~nm}^{3} \mathrm{~cm}^{-3} \mathrm{ppbC}^{-1}\right)$ and pine $\left(23( \pm 2) \times 10^{6} \mathrm{~nm}^{3} \mathrm{~cm}^{-3} \mathrm{ppbC}^{-1}\right)$. The growth efficiency of these stress-induced emissions was found to be rather low $\left(0.08( \pm 0.02) \mathrm{nm} \mathrm{h}^{-1} \mathrm{ppbC}^{-1}\right)$ with an intercept of $20( \pm 5) \mathrm{nm} \mathrm{h}^{-1}$. We have to note that the growth efficiency was found to be unaffected by VOC composition, specifically no effect of isoprene on this growth efficiency could be observed. The incremental particle mass yield obtained from stress induced emissions in this study was found to be 19.6 (土5.6) \%

As has been shown by Kiendler-Scharr et al. (2009b) the presence of isoprene in VOCs emitted from trees suppresses new particle formation. Kiendler-Scharr et al. (2009b) presented a simple parameterization to describe the suppression as function of relative concentration of isoprene in the BVOC mixture.

$\frac{N}{N_{0}}=\left(\frac{1}{1+1.5 \times R}\right)^{n}$

$N$ and $N_{0}$ are the maximum particle number concentrations formed in the presence and absence of isoprene, respectively, $R$ the fraction of carbon in the total mixture that is from isoprene, and $n$ proportional to the number of oxidation steps required for new particle formation (Kiendler-Scharr et al., 2009b). The coefficient 1.5 is a fitting parameter that was derived from MCM calculations for the system $\alpha$ pinene + isoprene (see the Supplement to Kiendler-Scharr et al., 2009b).

Applying the same mathematical procedure to the new particle formation observed from Grey poplar emissions, we found that the presence of isoprene is less effective in suppression of new particle formation in poplar emissions than in emissions from boreal tree species or $\alpha$-pinene as single compound. Figure 2 presents the poplar data (triangles and blue line) together with the fits from Kiendler-Scharr et al. (2009b) for boreal trees (green line) and $\alpha$-pinene (grey line), respectively. Using Eq. (1) we obtained an $n$ of 1.6 $( \pm 0.6)$, which is significantly lower than the $3.7( \pm 0.4)$ and $6.8( \pm 0.5)$ for boreal trees and $\alpha$-pinene, respectively. This indicates that the stress-induced poplar emissions form new particles more readily than MT dominated emissions from 


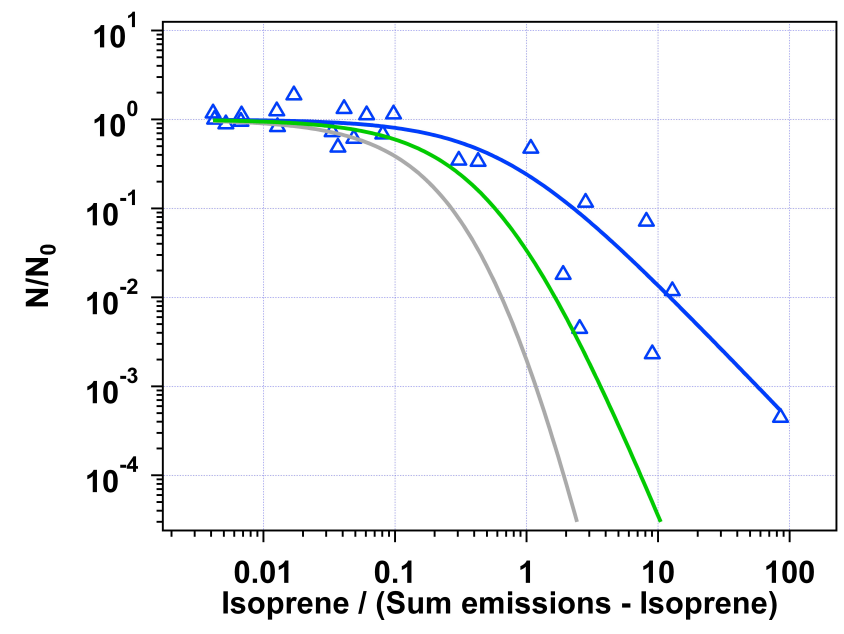

Fig. 2. $\mathrm{N} / \mathrm{N}_{0}$ as function of isoprene relative contribution to total VOC emissions for all poplar experiments (blue symbols, $[\mathrm{ppbC}] /[\mathrm{ppbC}])$. Fitting the data with $\left(1 /\left(1+1.5^{*} \mathrm{R}\right)\right)^{n}$ results in $\mathrm{n}$ of $1.6( \pm 0.6 \mathrm{SD})$ (blue line) which is significantly lower than the 3.7 $( \pm 0.4 \mathrm{SD})$ observed for mixed forests with MT dominated emissions and 6.8 ( $\pm 0.5 \mathrm{SD}$ ) for $\alpha$-pinene (green and grey lines, respectively, adapted from Kiendler-Scharr et al. (2009b)).

boreal tree species and the related new particle formation events are less affected by the presence of isoprene. Note that while the detailed mechanism by which isoprene suppresses nucleation remains unclear, the impact that isoprene has on nucleation in a given BVOC mixture is larger for BVOCs with low nucleation efficiency and high nucleation threshold. Most probably the suppression is related to the relative $\mathrm{OH}$ reactivities of isoprene and the sum of all other BVOC emissions. For several VOCs emitted from stressed poplar $\mathrm{OH}$ reaction rate constants are unknown, making a more detailed comparison of emissions with different BVOC classes impossible at this point.

Kiendler-Scharr et al (2009b) showed that the effect of isoprene in VOC mixtures is likely linked to a lower steady state $\mathrm{OH}$ concentration in the reaction chamber in the presence of isoprene. $\mathrm{OH}$ concentrations were derived from GCMS measurements of camphene and 1,8-cineole at the inlet and outlet of the reaction chamber in that work. In the present work we directly measured $\mathrm{OH}$ concentrations using Laser Induced Fluorescence. Figure 3 presents time series of isoprene (red symbols), monoterpenes (green triangles), sesquiterpenes (green circles) and MeSA (light blue circles) as measured with the PTR-MS. As indicated by the yellow line, photosynthetic active radiation (PAR) in the plant chamber was switched off at 16:00, resulting in reduced emissions from the poplar plant within minutes. In particular the lightdependent emission of isoprene was instantly stopped when switching off the lights in the plant chamber. Also shown in Fig. 3 are the measured $\mathrm{OH}$ concentration (blue crosses) and particle number concentration (black line) in the reaction

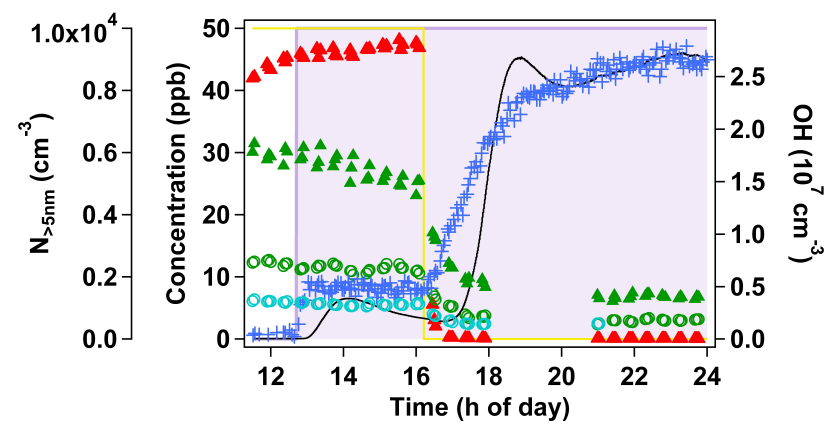

Fig. 3. Time series of isoprene (red symbols), monoterpenes (green triangles, for clearer visualization MTx20 is displayed), sesquiterpenes (green circles) and MeSA (light blue circles) as measured with the PTR-MS. Switching off the photosynthetic active radiation in the plant chamber (yellow line) causes an instantaneous drop of isoprene emissions to nearly zero. $\mathrm{OH}$ concentrations (blue crosses) increase after isoprene decrease, subsequently followed by an increase of particle number density (black dotted line). The purple shaded area indicates the time during which $\mathrm{OH}$ was produced by $\mathrm{O}_{3}$ photolysis.

chamber. Upon switching on the UV-lamps in the reaction chamber (12:30, indicated by light purple background), $\mathrm{OH}$ radicals are formed from ozone photolysis and new particle formation is initiated. As can be seen clearly, the decrease in isoprene emissions after switch off of the assimilation light in the plant chamber, resulted in an increase in $\mathrm{OH}$ concentrations in the reaction chamber, accompanied by an increase in new particle formation. The increase of $\mathrm{OH}$ concentration in the otherwise unchanged reaction chamber can be explained by the constant source strength and the decreasing sink of $\mathrm{OH}$, i.e. reaction with VOCs which decreased from a total of $65 \mathrm{ppb}$ to $6 \mathrm{ppb}$ within $90 \mathrm{~min}$ after switching off PAR. This decrease is dominated by the decrease of isoprene from $46.5 \mathrm{ppb}$ to $0.1 \mathrm{ppb}$.

While isoprene was shown to suppress new particle formation (Kiendler-Scharr et al., 2009b), no effect on particle growth rate was observed in the present experiments. Isoprene is also known to have a small but significant yield of SOA mass formation. Depending on seed aerosol, initial precursor concentration and relative $\mathrm{NO}_{\mathrm{x}}$ levels, SOA yields in the range of 1-5\% were reported in the literature (Kroll et al., 2005; Dommen et al., 2006; Kroll et al., 2006; Dommen et al., 2009). Including SOA from isoprene in calculations of the global SOA burden increases SOA by factors between 0.5 and 2 depending on scenarios used (Henze and Seinfeld, 2006).

In order to investigate the contribution of isoprene to SOA mass formation we performed an experiment in which fully deuterated isoprene was added from an artificial source to the stress-induced, but unlabelled VOC emissions of a nonisoprene emitting poplar. This plant emitted only negligible amounts of isoprene. The contribution of isoprene to the 


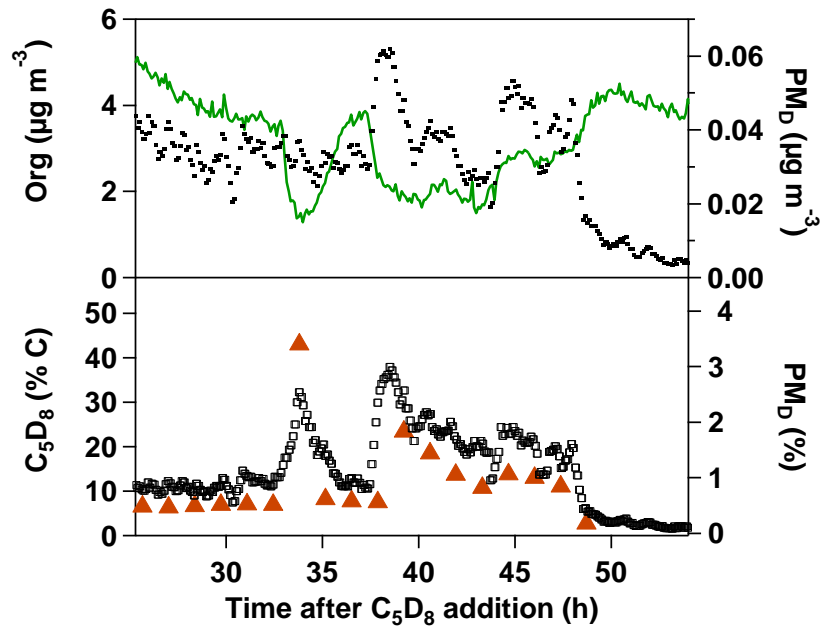

Fig. 4. SOA was produced by $\mathrm{OH}$-initiated oxidation of VOCs released from an ozone stressed non-isoprene emitting poplar (98$126 \mathrm{ppbC})$, and $\mathrm{C}_{5} \mathrm{D}_{8}(6-80 \mathrm{ppbC})$ with absolute concentrations of organics (green line, left scale) and $\mathrm{PM}_{D}$ (black filled squares, right scale) given in the upper panel. Contribution of deuterated isoprene $\left(\mathrm{C}_{5} \mathrm{D}_{8}\right)$ to the gas phase (red triangles, left scale) and contribution of $\mathrm{PM}_{D}$ (black open squares, right scale) to SOA formed from the mixture are shown in the lower panel.

total VOC emissions from the stressed plant was less than $0.5 \%$. Deuterated isoprene was detected with GC-MS and PTR-MS as described in the experimental section. Additionally the high-resolution capabilities of the AMS were exploited to determine the mass fraction of aerosol produced from $\mathrm{C}_{5} \mathrm{D}_{8}$ oxidation. Figure 4 summarizes the observations for gas and particle phase deuterated fractions. As described in the experimental section four oxygenated and six $C_{x} D_{y}$ peaks could be identified ranging from nominal $\mathrm{m} / \mathrm{z} 30$ to 76. No ions with carbon numbers larger than 5 were detected to be deuterated and no ions containing both $\mathrm{D}$ and $\mathrm{H}$ were identified. The deuterated particle mass $\left(\mathrm{PM}_{\mathrm{D}}\right)$ was defined as sum of all deuterated ions. Note that the list of ions used was defined by those peaks unambiguously separated from neighbouring non-deuterated ions. Likely the sum of these ions' signals represents a lower limit for the SOA mass from isoprene oxidation products in the particles. The yield calculated here therefore is a lower limit of SOA yield from isoprene.

The fractional abundance of $\mathrm{PM}_{\mathrm{D}}$ in the aerosol tracks the temporal evolution of the contribution of deuterated isoprene to the total VOCs (Fig. 4). On average a gas phase fraction of $13.4 \% \mathrm{C}$ in the form of deuterated isoprene translated into a $\mathrm{PM}_{\mathrm{D}}$ of $1.6 \%$ between 40 and $47 \mathrm{~h}$ after first addition of deuterated isoprene to the system. Taking into account the above mentioned fractional mass yield of $19.6 \%$ observed for the overall poplar emissions containing no isoprene, a fractional SOA mass yield of $2.5( \pm 0.3) \%$ for deuterated isoprene is observed throughout the experiment. This calcula- tion is based on the known isoprene consumption in the reaction chamber and measured deuterated mass in the particles. Note that taking into account the $11 \%$ larger mass of $\mathrm{C}_{5} \mathrm{D}_{8}$ compared to $\mathrm{C}_{5} \mathrm{H}_{8}$, the mass yield of unlabelled isoprene would be $2.3( \pm 0.3) \%$. This value agrees generally well with literature data. Note that in contrast to many other experiments the present experiment was performed under low concentrations for both seed aerosol and $\mathrm{NO}_{\mathrm{x}}(<200 \mathrm{ppt})$. The finding of a SOA yield for isoprene comparable to literature data despite its effect on new particle number formation is interesting and supports that the suppressing effect of isoprene acts at very early stages of the formation of the nucleating species, most likely by the competition for $\mathrm{OH}$ as proposed by Kiendler-Scharr et al. (2009b). While the isoprene $\mathrm{OH}$ oxidation products do not nucleate to form new particles, they do partition into SOA thus contributing to SOA mass formation.

\section{Summary and conclusion}

The use of Grey poplar mutants differing in isoprene emission potential served as a unique option to investigate the influence of isoprene on new particle formation in a natural emitted VOC mixture. Inducing stress situations by ozone pulses enabled simulation of pathogen-induced VOC emissions, dominated by sesquiterpene and aromatic VOC emissions. The photochemical formation of SOA was found to be efficient in this VOC mixture with number efficiency of 6.4 $( \pm 1.2) \mathrm{s}^{-1} \mathrm{~cm}^{-3} \mathrm{ppbC}^{-1}$. Isoprene was found to suppress new particle formation similarly to observations made with emissions dominated by monoterpenes (Kiendler-Scharr et al., 2009b) albeit the exponent of suppression was lower for new particle formation from poplar emissions (1.6 \pm 0.6$)$, compared to emissions from boreal tree species $(3.7 \pm 0.4)$. This indicates that isoprene is less effective in quenching new particle formation when the stress-induced emission patterns are composed of sesquiterpene and aromatic VOCs compared to a situation, where the emissions contain mainly monoterpenes (Mentel et al., 2009). The direct measurement of $\mathrm{OH}$ concentration in our reaction chamber revealed that a decrease in VOCs - and thus decrease in $\mathrm{OH}$ sink - increases steady state $\mathrm{OH}$ concentrations. The increase in $\mathrm{OH}$ concentration was accompanied by an increase in new particle formation, implying that $\mathrm{OH}$ radical chemistry plays an important role in new particle formation from VOCs emitted by plants. Mass spectral analysis of the SOA revealed a fractional mass yield of $2.3 \%$ of isoprene in this biogenic SOA in accordance with literature data. This finding is also consistent with particle growth rates - opposite to nucleation rates - being unaffected by the presence of isoprene in the emission mixture.

The increasing scarcity of fossil fuels, associated with the combustion of fossil fuels causing increase of greenhouse gas (GHG) emissions, raised growing interest in renewable 
energy sources and develops an enormous pressure on land use change (Wiedinmyer et al., 2006). In all scenarios for future energy supply, fuels from biomass - so-called biofuels - and/or other energy sources from biomass, play an important role (Demirbas, 2008). Recent comprehensive analyses (Hewitt et al., 2009) demonstrated that conversion of tropical rainforest to oil palm plantations in Malaysia results in enhanced isoprene emission that lead to $\mathrm{O}_{3}$ formation.

A recent long-term outdoor study (Behnke et al. 2011) with non-isoprene-emitting poplars - the same lines used in the present work - in the moderate climate of Central Europe revealed no remarkable difference between emitting and non-emitting trees with respect to plant growth and wood quality. However, and in addition to the social and political decision for the cultivation of genetically modified plants, more real-field trials under strongly contrasting climatic and soil conditions are needed to clarify conclusively whether isoprene-free poplars are an option for the second generation of biomass plants, either generated by genetic manipulation or classically by selection of low emitting phenotypes.

Keeping in mind that all fast growing tree species (poplars, willows, eucalypts) are among the strongest emitters of isoprene and monoterpenes (Kesselmeier and Staudt, 1999) the large scale extension of woody biomass plantations expected in future might change the relative abundance of isoprene in VOC mixtures with implications for both gas phase oxidation capacity and the nucleation potential. A decrease in new particle formation potential from VOC emissions from a given land area constitutes the change of an essential element in biosphere atmosphere climate feedback mechanisms. Further research is needed to fully understand the driving mechanisms in this suppression of new particle formation and its potential change and impacts under future climate scenarios.

Acknowledgements. The work was supported by the German Science Foundation (DFG) (SCHN653/4 to J.-P. S.) within the German joint research group "Poplar - A Model to Address Tree-Specific Questions" and by the European Community's Seventh Framework Programme ([FP7/2007-2013]) EU project PEGASOS under grant agreement no. 265307.

Edited by: H. Saathoff

\section{References}

Allan, J. D., Delia, A. E., Coe, H., Bower, K. N., Alfarra, M. R., Jimenez, J. L., Middlebrook, A. M., Drewnick, F., Onasch, T. B., Canagaratna, M. R., Jayne, J. T., and Worsnop, D. R.: A generalised method for the extraction of chemically resolved mass spectra from aerodyne aerosol mass spectrometer data, J. Aerosol Sci., 35, 909-922, 2004.

Behnke, K., Ehlting, B., Teuber, M., Bauerfeind, M., Louis, S., Hänsch, R., Polle, A., Bohlmann, J., and Schnitzler, J. P.: Transgenic non-isoprene emitting poplars don't like it hot, Plant J., 51, 485-499, 2007.
Behnke, K., Kleist, E., Uerlings, R., Wildt, J., Rennenberg, H., and Schnitzler, J. P.: RNAi-mediated suppression of isoprene biosynthesis in hybrid poplar impacts ozone tolerance, Tree Physiol., 29, 725-736, 2009.

Behnke, K., Grote, R., Brüggemann, N., Zimmer, I., Zhou, G., Elobeid, M., Janz, D., Polle, A., and Schnitzler, J. P.: Isoprene emission-free poplars - a chance to reduce the impact from poplar plantations on the atmosphere, New Phytologist, doi:10.1111/j.1469-8137.2011.03979.x, 2011.

Canagaratna, M. R., Jayne, J. T., Jimenez, J. L., Allan, J. D., Alfarra, M. R., Zhang, Q., Onasch, T. B., Drewnick, F., Coe H., Middlebrook, A., Delia, A., Williams, L. R., Trimborn, A. M., Northway, M. J., DeCarlo, P. F., Kolb, C. E., Davidovits, P., and Worsnop, D. R.: Chemical and microphysical characterization of ambient aerosols with the aerodyne aerosol mass spectrometer, Mass Spectrom. Rev., 26, 185-222, 2007.

Demirbas, A.: Biofuels sources, biofuel policy, biofuel economy and global biofuel projections, Ener. Convers. Manage., 49, 2106-2116, 2008.

Dommen, J., Hellen, H., Saurer, M., Jaeggi, M., Siegwolf, R., Metzger, A., Duplissy, J., Fierz, M., and Baltensperger, U.: Determination of the Aerosol Yield of Isoprene in the Presence of an Organic Seed with Carbon Isotope Analysis, Environ. Sci. Technol., 43, 6697-6702, 2009.

Dommen, J., Metzger, A., Duplissy, J., Kalberer, M., Alfarra, M. R., Gascho, A., Weingartner, E., Prévôt, A. S. H., Verheggen, B., and Baltensperger, U.: Laboratory observation of oligomers in the aerosol from isoprene/ $\mathrm{NO}_{\mathrm{x}}$ photooxidation, Geophys. Res. Lett., 33, L13805, doi:10.1029/2006GL026523, 2006.

Dudareva, N., Pichersky, E., and Gershenzon, J.: Biochemistry of plant volatiles, Plant Physiol., 135, 1993-2011, 2004.

Fuentes, J. D., Lerdau, M., Atkinson, R., Baldocchi, D., Bottenheim, J. W., Ciccioli, P., Lamp, C., Geron, C., Gu, L., Guenther, A., Sharkey, T. D., and Stockwell, W.: Biogenic hydrocarbons in the atmospheric boundary layer: a review, B. Am. Meteorol. Soc., 81, 1537-1575, 2000.

Ghirardo, A., Gutknecht, J., Zimmer, I., Brüggemann, N., and Schnitzler, J. P.: Biogenic volatile organic compound and respiratory $\mathrm{CO}_{2}$ emissions after ${ }^{13} \mathrm{C}$-labeling: online tracing of $\mathrm{C}$ translocation dynamics in poplar plants. Public Library of Science ONE 6: e17393, 2011.

Ghirardo, A., Koch, K., Taipale, R., Zimmer, I., Schnitzler, J. P., and Rinne, J.: Determination of de novo and pool emissions of terpenes in four common boreal/alpine trees by means of ${ }^{13} \mathrm{CO}_{2}$ labeling and PTR-MS analysis, Plant Cell Environ., 33, 781-792, 2010.

Guenther, A.: Estimates of global terrestrial isoprene emissions using MEGAN, Atmos. Chem. Phys., 7, 4327-4327, doi:10.5194/acp-7-4327-2007, 2007.

Guenther, A., Hewitt, C. N., Erickson, D., Fall, R., Geron, C., Graedel, T., Harley, P., Klinger, L., Lerdau, M., McKay, W. A., Pierce, T., Scholes, B., Steinbrecher, R., Tallamraju, R., Taylor, J., and Zimmerman, P.: A Global-Model of Natural Volatile Organic-Compound Emissions, J. Geophys. Res.-Atmos., 100, 8873-8892, 1995.

Hallquist, M., Wenger, J. C., Baltensperger, U., Rudich, Y., Simpson, D., Claeys, M., Dommen, J., Donahue, N. M., George, C., Goldstein, A. H., Hamilton, J. F., Herrmann, H., Hoffmann, T., Iinuma, Y., Jang, M., Jenkin, M. E., Jimenez, J. L., 
Kiendler-Scharr, A., Maenhaut, W., McFiggans, G., Mentel, Th. F., Monod, A., Prvt, A. S. H., Seinfeld, J. H., Surratt, J. D., Szmigielski, R., and Wildt, J.: The formation, properties and impact of secondary organic aerosol: current and emerging issues, Atmos. Chem. Phys., 9, 5155-5236, doi:10.5194/acp-95155-209, 2009.

Hao, L. Q., Yli-Pirilä, P., Tiitta, P., Romakkaniemi, S., Vaattovaara, P., Kajos, M. K., Rinne, J., Heijari, J., Kortelainen, A., Miettinen, P., Kroll, J. H., Holopainen, J. K., Smith, J. N., Joutsensaari, J., Kulmala, M., Worsnop, D. R., and Laaksonen, A.: New particle formation from the oxidation of direct emissions of pine seedlings, Atmos. Chem. Phys., 9, 8121-8137, doi:10.5194/acp9-8121-2009, 2009.

Hao, L. Q., Romakkaniemi, S., Yli-Pirilä, P., Joutsensaari, J., Kortelainen, A., Kroll, J. H., Miettinen, P., Vaattovaara, P., Tiitta, P., Jaatinen, A., Kajos, M. K., Holopainen, J. K., Heijari, J., Rinne, J., Kulmala, M., Worsnop, D. R., Smith, J. N., and Laaksonen, A.: Mass yields of secondary organic aerosols from the oxidation of alpha-pinene and real plant emissions, Atmos. Chem. Phys.,, 11, 1367-1378, 10.5194/acp-11-1367-2011, 2011.

Heiden, A. C., Kobel, K., Langebartels, C., Schuh-Thomas, G., and Wildt, J.: Emissions of Oxygenated Volatile Organic Compounds from Plants Part I: Emissions from Lipoxygenase Activity, J. Atmos. Chem., 45, 143-172, 2003.

Henze, D. K. and Seinfeld, J. H.: Global secondary organic aerosol from isoprene oxidation. Geophys. Res. Lett., 33, L09812, doi:10.1029/2006GL025976, 2006.

Hewitt, C. N., MacKenzie, A. R., Di Carlo, P., Di Marco, C. F., Dorsey, J. R., Evans, M., Fowler, D., Gallagher, M. W., Hopkins, J. R., Jones, C. E., Langford, B., Lee, J. D., Lewis, A. C., Lim, S. F., McQuaid, J., Misztal, P., Moller, S. J., Monks, P. S., Nemitz, E., Oram, D. E., Owen, S. M., Phillips, G. J., Pugh, T. A. M., Pyle, J. A., Reeves, C. E., Ryder, J., Sion, J., Skiba, U., Stewart, D. J.: Nitrogen management is essential to prevent tropical oil palm plantations from causing ground-level ozone pollution, Proc. Natl. Acad. Sci. USA, 106, 18447-18451, 2009.

Hofzumahaus, A., Rohrer, F., Lu, K. D., Bohn, B., Brauers, T., Chang, C. C., Fuchs, H., Holland, F., Kita, K., Kondo, Y., Li, X., Lou, S. R., Shao, M., Zeng, L. M., Wahner, A., and Zhang, Y. H.: Amplified Trace Gas Removal in the Troposphere, Sci., 324, 1702-1704, 2009.

Holland, F., Hofzumahaus, A., Schäfer, J., Kraus, A., and Pätz, H.W.: Measurements of $\mathrm{OH}$ and $\mathrm{HO}_{2}$ radical concentrations and photolysis frequencies during BERLIOZ, J. Geophys. Res., 108, 8246, doi:10.1029/2001JD001393, 2003.

Holopainen, J. K. and Gershenzon, J.: Multiple stress factors and the emission of plant VOCs, Trends Plant Sci., 15, 176-184, 2010.

IPC: Report of the 23nd session of the international poplar commission, Beijing, China, ftp://ftp.fao.org/docrep/fao/011/k3380e/ k3380e.pdf, 27-30 October 2008.

Joutsensaari, J., Loivamki, M., Vuorinen, T., Miettinen, P., Nerg, A.-M., Holopainen, J. K., and Laaksonen, A.: Nanoparticle formation by ozonolysis of inducible plant volatiles, Atmos. Chem. Phys., 5, 1489-1495, doi:10.5194/acp-5-1489-2005, 2005.

Kanawade, V. P., Jobson, B. T., Guenther, A. B., Erupe, M. E., Pressley, S. N., Tripathi, S. N., and Lee, S.-H.: Isoprene suppression of new particle formation in a mixed deciduous forest, Atmos. Chem. Phys., 11, 6013-6027, doi:10.5194/acp-11-6013-
2011, 2011.

Kesselmeier, J. and Staudt, M.: Biogenic organic compounds (VOC): An overview on emission, physiology and ecology, J. Atmos. Chem., 33, 23-88, 1999.

Kesselmeier, J., Ciccioli, P., Kuhn, U., Stefani, P., Biesenthal, T., Rottenberger, S., Wolf, A., Vitullo, M., Valentini, R., Nobre, A., Kabat, P., and Andreae, M. O.: Volatile organic compound emissions in relation to plant carbon fixation and the terrestrial carbon budget, Global Biogeochem. Cy., 16, 1126, doi:10.1029/2001GB001813, 2002.

Kiendler-Scharr, A., Zhang, Q., Hohaus, T., Kleist, E., Mensah, A., Mentel, T., Spindler, C., Uerlings, R., Tillmann, R., and Wildt, J.: Aerosol Mass Spectrometric Features of Biogenic SOA: Observations from a Plant Chamber and in Rural Atmospheric Environments, Environ. Sci. Technol. 43, 8166-8172, 2009a.

Kiendler-Scharr, A., Wildt, J., Dal Maso, M., Hohaus, T., Kleist, E., Mentel, T. F., Tillmann, R., Uerlings, R., Schurr, U., and Wahner, A.: New particle formation in forests inhibited by isoprene emissions, Nature, 461, 381-384, 2009b.

Kreuzwieser, J., Schnitzler, J. P., and Steinbrecher, R.: Biosynthesis of Organic Compounds Emitted by Plants, Plant Biol., 1, 149159, 1999.

Kroll, J. H., Ng, N. L., Murphy, S. M., Flagan, R. C., and Seinfeld, J. H.: Secondary organic aerosol formation from isoprene photooxidation under high- $\mathrm{NO}_{\mathrm{x}}$ conditions, Geophys. Res. Lett., 32, L18808, doi:10.1029/2005GL023637, 2005.

Kroll, J. H., Ng, N. L., Murphy, S. M., Flagan, R. C., and Seinfeld, J. H.: Secondary organic aerosol formation from isoprene photooxidation, Environ. Sci. Technol., 40, 1869-1877, 2006.

Kulmala, M., Suni, T., Lehtinen, K. E. J., Dal Maso, M., Boy, M., Reissell, A., Rannik, U., Aalto, P., Keronen, P., Hakola, H., Back, J. B., Hoffmann, T., Vesala, T., and Hari, P.: A new feedback mechanism linking forests, aerosols, and climate, Atmos. Chem. Phys., 4, 557-562, doi:10.5194/acp-4-557-204, 2004.

Lang-Yona, N., Rudich, Y., Mentel, T. F., Bohne, A., Buchholz, A., Kiendler-Scharr, A., Kleist, E., Spindler, C., Tillmann, R., and Wildt, J.: The chemical and microphysical properties of secondary organic aerosols from Holm Oak emissions, Atmos. Chem. Phys., 10, 7253-7265, doi:10.5194/acp-10-7253-2010, 2010.

Lelieveld, J., Butler, T. M., Crowley, J. N., Dillon, T. J., Fischer, H., Ganzeveld, L., Harder, H., Lawrence, M. G., Martinez, M., Taraborrelli, D., and Williams, J.: Atmospheric oxidation capacity sustained by a tropical forest, Nature, 452, 737-740, 2008.

Loreto, F. and Schnitzler, J. P.: Abiotic stresses and induced BVOCs, Trends Plant Sci., 15, 154-166, 2010.

Lu, K. D., Rohrer, F., Holland, F., Fuchs, H., Bohn, B., Brauers, T., Chang, C. C., Häseler, R., Hu, M., Kita, K., Kondo, Y., Li, X., Lou, S. R., Nehr, S., Shao, M., Zeng, L. M., Wahner, A., Zhang, Y. H., and Hofzumahaus, A.: Observation and modelling of $\mathrm{OH}$ and $\mathrm{HO}_{2}$ concentrations in the Pearl River Delta 2006: a missing $\mathrm{OH}$ source in a VOC rich atmosphere, Atmos. Chem. Phys. Discuss., 11, 11311-11378, doi:10.5194/acpd-11-113112011, 2011.

McFiggans, G., Coe, H., Burgess, R., Allan, J., Cubison, M., Alfarra, M. R., Saunders, R., Saiz-Lopez, A., Plane, J. M. C., Wevill, D., Carpenter, L., Rickard, A. R., and Monks, P. S.: Direct evidence for coastal iodine particles from Laminaria macroalgae - linkage to emissions of molecular iodine, Atmos. 
Chem. Phys., 4, 701-713, doi:10.5194/acp-4-701-2004, 2004.

Mentel, Th. F., Wildt, J., Kiendler-Scharr, A., Kleist, E., Tillmann, R., Dal Maso, M., Fisseha, R., Hohaus, Th., Spahn, H., Uerlings, R., Wegener, R., Griffiths, P. T., Dinar, E., Rudich, Y., and Wahner, A.: Photochemical production of aerosols from real plant emissions, Atmos. Chem. Phys., 9, 4387-4406, doi:10.5194/acp9-4387-2009, 2009.

Paulot, F., Crounse, J. D., Kjaergaard, H. G., Kurten, A., St Clair, J. M., Seinfeld, J. H., and Wennberg, P. O.: Unexpected Epoxide Formation in the Gas-Phase Photooxidation of Isoprene, Science, 325, 730-733, 2009.

Peeters, J. and Müller, J.-F.: $\mathrm{HO}_{\mathrm{x}}$ radical regeneration in isoprene oxidation via peroxy radical isomerisations. II: Experimental evidence and global impact, Phys. Chem. Chem. Phys., 12, 1422714235, doi:10.1039/c0cp00811g, 2010.

Ren, X., Olson, J. R., Crawford, J. H., Brune, W. H., Mao, J., Long, R. B., Chen G., Avery M. A., Sachse, G. W., Barrick, J. D., Diskin, G. S., Huey, L. G., Fried A., Cohen, R. C., Heikes, B., Wennberg, P., Singh, H. B., Richard, D. R. B., and Shetter, E.: HOx chemistry during INTEXA 2004: observation, model calculations and comparison with previous studies, J. Geophys. Res., 113, D05310, doi:10.1029/2007JD009166, 2008.

Sandermann, H., Ernst, D., Heller, W., and Langebartels, C.: Ozone: an abiotic elicitor of plant defence reactions, Trends Plant Sci., 3, 47-50, 1998.

Schnitzler, J. P., Louis, S., Behnke, K., and Loivamäki, M.: Poplar volatiles - biosynthesis, regulation and (eco)physiology of isoprene and stress-induced isoprenoids, Plant Biol., 12, 302-316, 2010 .
Tan, D., Faloona, I., Simpas, J. B., Brune, W., and Shepson, P. B.: $\mathrm{HO}_{\mathrm{x}}$ budgets in a deciduous forest: results from the PROPHET summer 1998 campaign, J. Geophys. Res., 106, 24407-24427, 2001.

Thornton, J. A., Woolridge, P. J., Cohen, R. C., Martinez, M., Harder, H., Brune, W. H., Williams, E. J., Roberts, J. M., Fehsenfeld, F. C., Hall, S. R., Shetter, R. E., Wert, B. P., and Fried, A.: Ozone production rates as a function of $\mathrm{NO}_{\mathrm{x}}$ abundances and $\mathrm{HO}_{\mathrm{x}}$ production rates in the Nashville urban plume, J. Geophys. Res., 107, 4146, doi:10.1029/2001JD000932, 2002.

Tunved, P., Hansson, H. C., Kerminen, V. M., Strom, J., Dal Maso, M., Lihavainen, H., Viisanen, Y., Aalto, P. P., Komppula, M., and Kulmala, M.: High natural aerosol loading over boreal forests, Science, 312, 261-263, 2006.

VanReken, T. M., Greenberg, J. P., Harley, P. C., Guenther, A. B., and Smith, J. N.: Direct measurement of particle formation and growth from the oxidation of biogenic emissions. Atmos. Chem. Phys., 6, 4403-4413, doi:10.5194/acp-6-4403-2006, 2006.

Whalley, L. K., Edwards, P. M., Furneaux, K. L., Goddard, A., Ingham, T., Evans, M. J., Stone, D., Hopkins, J. R., Jones, C. E., Karunaharan, A., Lee, J. D., Lewis, A. C., Monks, P. S., Moller, S. J., and Heard, D. E.: Quantifying the magnitude of a missing hydroxyl radical source in a tropical rainforest, Atmos. Chem. Phys., 11, 7223-7233, doi:10.5194/acp-11-7223-2011, 2011.

Wiedinmyer, C., Tie, X. X., Guenther, A., Neilson, R., and Granier, C.: Future changes in biogenic isoprene emissions: how might they affect regional and global atmospheric chemistry?, Earth Interact., 10, EI174, doi:10.1175/EI174.1, 2006. 